\title{
KORELASI ANTARA RESISTENSI SURVIVAL RATE DAN BODY CONDITION INDEX (BCI) DENGAN STRESS SUHU PADA KERANG HIJAU DI MUARA KAMAL, JAKARTA
}

\author{
Yasser Ahmed ${ }^{1}$, Armin Fabritzek ${ }^{2}$, Neviaty P. Zamani ${ }^{3}$, Karen Von Juterzenka ${ }^{3}$, Mark Lenz ${ }^{4}$ \\ ${ }^{1}$ Program Studi Pemanfaatan Sumberdaya Perikanan, FPIK, USNI \\ ${ }^{2} \mathrm{PhD}$ Student Mainz University, Germany \\ ${ }^{3}$ Departemen Ilmu dan Teknologi Kelautan, FPIK, IPB \\ ${ }^{4}$ Geomar, Germany
}

\begin{abstract}
ABSTRAK
Pergerakan organisme dipengaruhi oleh penyebaran alami dan aktivitas manusia.Beberapa spesies yang terbawa, memiliki sebaran yang melebihi distribusi batas normal oleh pengaruh tertentu (vector). Penelitian ini melakukan pengujian pada skala laboratorium untuk melihat survival rate yang terkait dengan body condition index selama diberikan stress suhu yang terkait perubahan iklim dan ini juga dapat dijadikan sebagai simulasi transportasi kapal, sehingga dapat diketahui pergerakan organisme.Distribusi organisme tersebut mempengaruhi kemampuan bertahan hidupselama transportasi.Oleh karena itu, perlu dilakukan penelitian dengan mengekspose grup pra-stress dan grup non stress sebelum masuk ke fase stress dan membandingkan survival rate dan body condition index (BCI) pada organisme tersebut. Organisme yang dipilih adalah Kerang Hijau (P. viridis) dengan menggunakan stress suhu.Pengukuran respon variabel dari organisme tersebut yaitu survival rate dan body condition index (BCI).Penelitian ini menunjukkan bahwa survival rate dan body condition index memiliki korelasi linier.
\end{abstract}

Kata kunci: Survival rate, Body condition index, stress suhu, Kerang Hijau, Muara Kamal

\section{PENDAHULUAN}

Latar Belakang

Pergerakan organisme dipengaruhi oleh penyebaran alami dan aktivitas manusia.Spesies yang terbawa memiliki sebaran yang melebihi distribusi batas normal oleh pengaruh tertentu (vector).Pergerakan organisme secara alami memiliki pergerakan yang terbatas.Spesies yang terbawa dapat mempengaruhi kerentanan pada stress yang baik disengaja maupun tidak disengaja. Spesies yang terbawa karena pengaruh alam seperti organisme yang bergerak akibat pergerakan arus dan beberapa organisme ada yang dapat bermigrasi ke area yang lain yang dapat melalui pergerakan arus; spesies yang terbawa akibat pengaruh aktivitas manusia baik disengaja seperti perdagangan ikan hias, aktivitas budidaya atau kegiatan manusia yang tidak disengaja seperti masukan air ballast dalam kapal (Baker et al. 2007). Berdasarkan Mead et al (2011), organisme yang paling banyak terdistribusi ke berbagai tempat karena air ballast dari kapal (Mead et al, 2011; Kaluza et al., 2010). Pertanyaannya adalah apakah spesies dapat bertahan pada stress suhu?Bagaimana respon spesies tersebut selama transportasi kapal? Spesies yang terbawa terdapat berbagai mekanisme (vector) yang tersedia untuk membawa organisme yang bersifat invasi akibat pengaruh perjalanan kapal dan menyebar dalam jumlah yang besar; akan tetapi hanya dalam jumlah kecil yang dapat bertahan dan menjadi pesaing (competitor) dengan spesies asli dalam mendapatkan makanan di lingkungan yang baru, sehingga ini disebut sebagai spesies yang invasif (invasive species). Spesies yang berinvasif dianggap 
sebagai spesies pendatang atau tidak asli yang dapat menyebabkan kerusakan ekosistem, sehingga berdampak pada perekonomian setempat, dan juga kesehatan masyarakat (Bax et al., 2003; ISAC, 2006).

\section{Perumusan Masalah}

Berdasarkan penelitian yang telah dilakukan sebelumnya menunjukkan bahwa biota laut avertebrata yang bersifat non native lebih tahan atau memiliki toleransi terhadap stress dibandingkan dengan biota native (asli) (Lenz et al, 2011).Hal ini makin diperparah dengan masuknya organisme baru di beberapa tempat belahan dunia yang telah terjadi dari seabad silam (Mead et al, 2011).Permasalahan yang timbul akibat penelitian tersebut diatas ada 2, yaitu:

1. Apakah Kerang Hijau memiliki resistensi untuk dapat tahan terhadap stress suhu?

2. Apakah Kerang Hijau dapat meningkatkan toleransinya selama transportasi?

\section{Tujuan}

Tujuan dari penelitian ini untuk menginvestigasi apakah Kerang Hijau dapat meningkatkan toleransinya terhadap stress suhu.

\section{METODOLOGI}

\section{Waktu dan tempat}

Penelitian ini dilakukan di Laboratorium Marine Habitat, Fakultas Perikanan dan Ilmu Kelautan, Institut Pertanian Bogor.Aktifitas penelitian ini dilakukan pada bulan April - September 2012.

\section{Bahan}

Bahan-bahan yang digunakan pada penelitian ini adalah sebagai berikut:

\begin{tabular}{|c|c|c|c|}
\hline Bahan & Tipe & Spesifikasi & Fungsi \\
\hline Air laut & & $\begin{array}{l}\text { Salinitas: } 33-35 \\
\text { \%oyang diambil dariTeluk } \\
\text { Jakarta }\end{array}$ & \\
\hline Garam & & & $\begin{array}{l}\text { Untuk mengatur } \\
\text { perbedaan salinitas }\end{array}$ \\
\hline $\begin{array}{l}\text { Penyambung selang } \\
(\mathrm{L}, \mathrm{I}, \mathrm{T})\end{array}$ & & & $\begin{array}{l}\text { Untuk menyambung } \\
\text { selang aerasi }\end{array}$ \\
\hline Toples & Jack Family & Volume 1,5 liter & $\begin{array}{l}\text { Tempat organisme } \\
\text { disimpan }\end{array}$ \\
\hline Bak air & & Tanki fiber & $\begin{array}{l}\text { Untuk menyimpan } \\
\text { air tawar pada pilot } \\
\text { studi dan penelitian } \\
\text { utama }\end{array}$ \\
\hline $\begin{array}{l}\text { Pipa transparan dan } \\
\text { kain jaring }\end{array}$ & & & $\begin{array}{l}\text { Untuk membuat } \\
\text { frame penelitian } \\
\text { (pilot studi) }\end{array}$ \\
\hline Jangka sorong & & $\begin{array}{l}\text { - } 15 \mathrm{~cm}(\max ) \\
\text { - } 0.05 \mathrm{~cm}(\text { accuracy })\end{array}$ & $\begin{array}{l}\text { Untuk mengukur } \\
\text { panjang dan lebar } \\
\text { kerang hijau }\end{array}$ \\
\hline
\end{tabular}




\begin{tabular}{|l|l|l|l|}
\hline & & $\begin{array}{l}\bullet \operatorname{6inc}(\max .) \\
\bullet 1 / 128 \text { inches(accuracy) }\end{array}$ & \\
\hline
\end{tabular}

Bahan-bahan yang digunakan pada penelitian ini adalah sebagai berikut (lanjutan):

\begin{tabular}{|c|c|c|c|}
\hline Bahan & Tipe & Spesifikasi & Fungsi \\
\hline Timbangan digital & $\begin{array}{l}\text { "Lucky" } \\
\text { (pocketscale) }\end{array}$ & $\begin{array}{l}\text { - Digital scale } \\
\text { - Capacity:200gx0.01g }\end{array}$ & $\begin{array}{l}\text { Untuk mengukur } \\
\text { berat kerang hijau }\end{array}$ \\
\hline Thermometer Digital & $\begin{array}{l}\text { Krisbow } \\
\text { KW06-308 }\end{array}$ & $\begin{array}{l}\text { - } 40{ }^{0} \mathrm{C}-250{ }^{0} \mathrm{C} \\
\text { - } 40{ }^{0}-482{ }^{0} \mathrm{~F} \\
\text { - Resolution:0.1 }{ }^{0}\end{array}$ & $\begin{array}{l}\text { Untuk mengukur } \\
\text { suhu di dalam bak } \\
\text { penampungan air laut }\end{array}$ \\
\hline Tongkat bambu kecil & & Bambu & $\begin{array}{l}\text { Alat untuk mengecek } \\
\text { kerang hijau }\end{array}$ \\
\hline Kamera & Nikon & & $\begin{array}{lr}\text { Untuk mengambil } \\
\text { gambar } \\
\text { dokumentasi }\end{array}$ \\
\hline Pakan & Sera marine coraliquid & $\begin{array}{l}\text { Food for filter feeding } \\
\text { invertebrates }\end{array}$ & $\begin{array}{ll}\text { Makanan } & \text { untuk } \\
\text { kerang hijau } & \end{array}$ \\
\hline Oven & Heraeus & & $\begin{array}{l}\text { Untuk mengeringkan } \\
\text { kerang hijau }\end{array}$ \\
\hline Data sheet & & Paper & Untuk catatan \\
\hline Refractometer & $\begin{array}{l}\text { Atago(S/Mill-E) } \\
\text { (Hand-held } \\
\text { refractometer, } \\
\text { MadeinJapan) }\end{array}$ & Salinity0 100\%о & $\begin{array}{ll}\text { Untuk mengukur } \\
\text { salinitas }\end{array}$ \\
\hline $\begin{array}{l}\text { Nitrateand } \\
\text { Nitrite } \\
\text { Aquariumtest strips }\end{array}$ & $\begin{array}{l}\text { API(Aquarium } \\
\text { Pharmaceuticals) }\end{array}$ & $\begin{array}{l}\text { Forfreshand } \\
\text { saltwateraquarium } \\
\text { Nitrite }\left(\mathrm{NO}_{2}^{-{ }^{-}}\right): 0- \\
0.5-1-3-5-10 \\
\text { Nitrate }\left(\mathrm{NO}_{3}^{-{ }^{-}}\right): 0-20 \\
-40-80-160-200 \\
\end{array}$ & $\begin{array}{l}\text { Untuk mengukur } \\
\text { Nitrat dan Nitrit air } \\
\text { laut }\end{array}$ \\
\hline $\begin{array}{l}\text { Ammonia } \\
\text { aquariumtest strips }\end{array}$ & $\begin{array}{l}\text { API(Aquarium } \\
\text { Pharmaceuticals) }\end{array}$ & $\begin{array}{l}\text { - Forfreshand } \\
\text { saltwateraquarium } \\
\text { - Ammonia (ppm } \\
(\mathrm{mg} / \mathrm{L})): 0-0.5-1.0 \text { - } \\
3.0-6.0\end{array}$ & $\begin{array}{l}\text { Untuk mengukur } \\
\text { amoniak air laut }\end{array}$ \\
\hline $\begin{array}{l}\mathrm{pH} \text { aquariumtest } \\
\text { strips }\end{array}$ & $\begin{array}{l}\text { API(Aquarium } \\
\text { Pharmaceuticals) }\end{array}$ & $\begin{array}{l}\text { Forfreshand } \\
\text { saltwateraquarium } \\
\text { pH air tawar: } 6.0- \\
6.5-7.0-7.5-8.0- \\
8.5-9.0 \\
\text { pH air laut: } 6.0-6.5 \\
-7.0-7.5-8.0-8.5 \\
-9.0\end{array}$ & $\begin{array}{l}\text { Untuk mengukur } \mathrm{pH} \\
\text { air laut }\end{array}$ \\
\hline $\begin{array}{l}\text { Tanki filter dan } \\
\text { pompa telah tersedia } \\
\text { di Laboratorium }\end{array}$ & & & $\begin{array}{l}\text { Filterisasi dan pompa } \\
\text { air laut }\end{array}$ \\
\hline
\end{tabular}




\section{Metode \\ Pemilihan organisme dan lokasi sampling}

Dalam memilih organisme, ada beberapa kriteria yang perlu diperhatikan yaitu: 1). Kerang termasuk biota asli (native) di Indo - Pasific dan invasive di area yang lain, 2). Secara umum dapat ditemukan di tanki air ballast dan lambung kapal (Leeand Chown,2007), sehingga organisme ini relevan untuk dijadikan sebagai simulasi transportasi kapal, 3). Organisme mudah didapatkan di berbagai tempat dan bersifat filter feeder.Lokasi sampling dilakukan di Muara Kamal, Jakarta Utara, dimana kerang hijau dibudidayakan oleh nelayan setempat untuk menjadi komoditas ekonomi.

\section{Pengambilan dan transportasi organisme}

Sampel dibawa dari lokasi ke laboratorium.Pengambilan sampel kerang hijau dilakukan bersama para nelayan setempat dengan menggunakan perahu.Kerang hijau diambil di daerah budidaya dengan konstruksi tiang bambu.Selanjutnya, kerang hijau dibawa dari Muara Kamal ke laboratorium dengan menggunakan mobil.Organisme tersebut disimpan dalam cool box tanpa air laut.Pada bagian bawah cool box tersebut, diisi dengan es balok yang telah dipecahkan beberapa bagian dan ditutup dengan stereofoam.Hal ini dilakukan untuk tetap dingin dan menjaga metabolisme organisme. Perjalanan transportasi perpindahan organisme membutuhkan waktu 2 jam dari Muara Kamal ke laboratorium. Setelah tiba di laboratorium, organisme dibersihkan dari parasit yang menempel.Selanjutnya, organisme disimpan dalam akuarium untuk aklimasi.

\section{Aklimasi dan pemberian makanan}

Aklimasi adalah respon organisme terhadap perubahan lingkungan seperti suhu, salinitas, oksigen, dan lain-lain, yang diamati di laboratorium untuk membedakan pengaruh dan respon pada perubahan fisiologi, aktivitas, pertumbuhan, dan sebagainya (Nielsen, 1990;BrabyandSomero,2006).Tujuan dari aklimasi agar organisme dapat beradaptasi pada kondisi laboratorium (suhu, salinitas, oksigen) hingga mencapai 1\% mortalitas. Selama akllimasi, pergantian air dan pemberian pakan terus dilakukan. Setengah air laut dalam ember plastik (40 liter) diganti setiap hari. Hari pertama dan kedua pada aklimasi, pergantian air dilakukan dua kali sehari dan hari selanjutnya dilakukan sekali sehari. Seluruh organisme di aklimasi sebelum penelitian.

Kerang hijau diberi makan dengan Sera marine coraliquid (Nanochloropsisaculata,Phaeodactylumtricornutum,Chlorella2-20microns) yang memiliki konsentrasi 1,58x 107. Pada hari pertama dan kedua aklimasi, organisme tidak diberi makan karena stress selama transportasi dari lokasi pengambilan ke laboratorium. Setelah itu, organisme diberi makan pada hari ketiga.Pemberian makan dilakukan setiap hari dengan konsentrasi $0,0125 \mathrm{ml} / \mathrm{ind}$.

Total organisme aklimasi sebanyak 480 individu yang disimpan dalam 12akuarium. Masing-masing akuarium berjumlah 40 individu.

\section{Desain eksperimen dan analisis data}

Eksperimen ini dilakukan dengan mendesign waktu perjalanan kapal dan juga dapat dikaitkan dengan perubahan iklim yang terkait dengan stress suhu. Material kapal yang didominasi oleh material baja yang bersifat konduktor, sehingga sesuai dengan stress yang diberikan yaitu suhu. Pada eksperimen laboratorium, organisme akan dipaparkan pada stress yang mirip atau serupa dengan yang terjadi selama perjalanan transportasi oleh kapal dan 
juga dapat menyebabkan mortalitas sekitar $80 \%$ selama 10 hari (pre stress). Setelah masa pre stress, organisme yang hidup dan bertahan pada salah satu grup diberi waktu untuk recovery selama 2 minggu dan grup yang lain langsung kembali dipaparkan stress seperti pada kondisi pre stress di tahap kedua (second stress). Selanjutnya membandingkan antara organisme yang hidup (survival) antara organisme yang terpapar pada second stress dan organisme yang akan terpapar stress (non stress) untuk menginvestigasi apakah grup yang terpapar second stress dapat meningkatkan ketahanannya selama simulasi transportasidan juga apakah body condition index (BCI) meningkat atau menurun selama stress. Pada eksperimen ini, memiliki 4 grup yang terdiri dari grup second stress dengan recovery (grup A); grup second stress tanpa recovery (grup B); selanjutnya, grup single stress (grup C) dan grup control (grup D). Pada eksperimen ini, membandingkan grup second stress dengan recovery dan grup single stress (grup A dan grup C), grup second stress tanpa recovery dan grup single stress (grup B dan grup C)

(Gambar 1).

Pada analisa data menggunakan program R (version 2.14.2). Kurva Kaplan Meier untuk menganalisis organisme yang tetap hidup atau survival (log rank test), dan normalitas pada body condition index (BCI) menggunakan Shapiro wilk test.

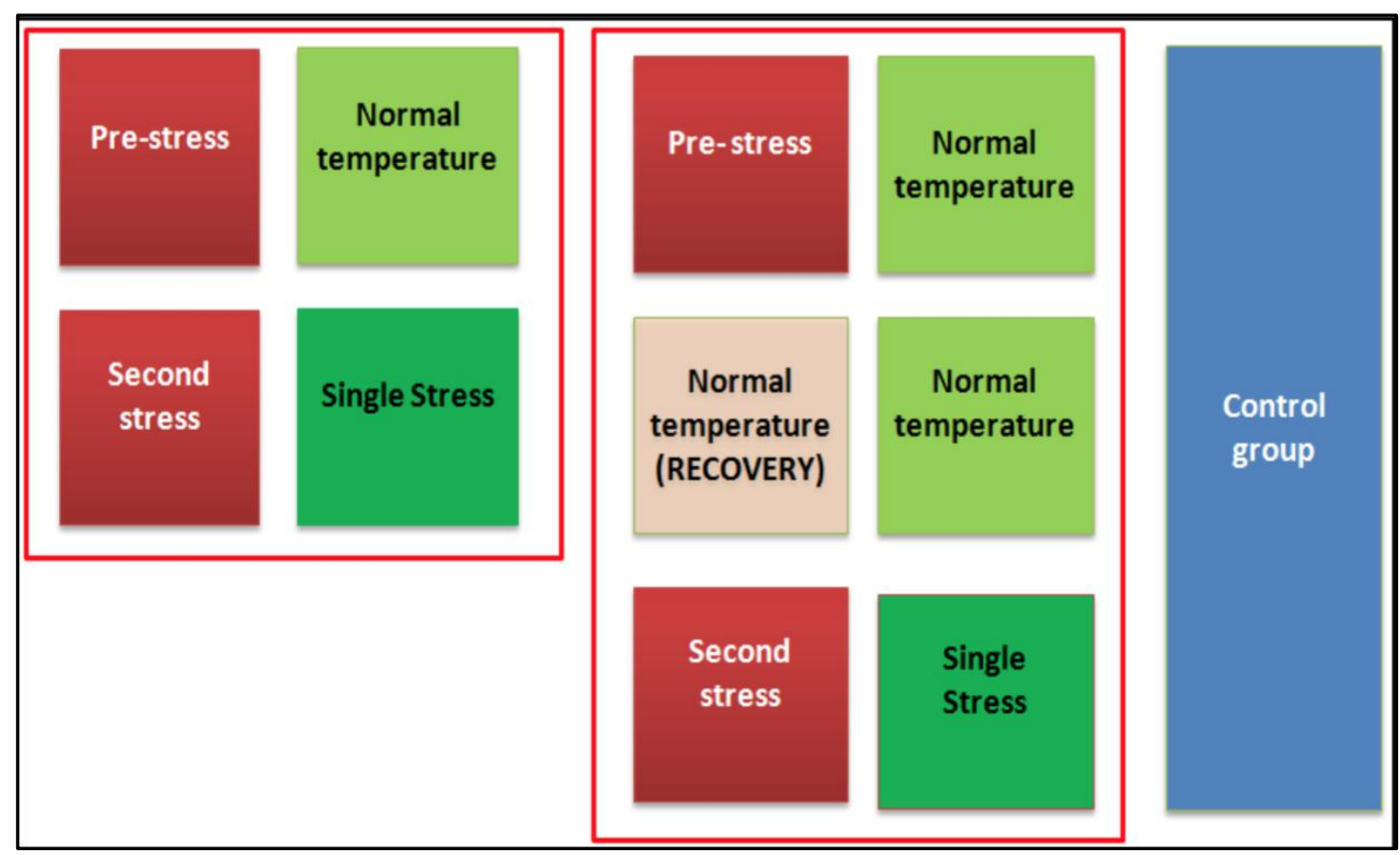

Gambar 1. Desain eksperimen

\section{Variable respon organisme: Survival rate dan Body condition index $(\mathrm{BCI})$}

Variabel respon untuk penelitian Kerang Hijau ini adalah Survival dan Body Condition Index (BCI).Survival rate adalah jumlah individu yang survive selama eksperimen. Pengecekan survival Kerang Hijau dengan menggunakan bambu dansiphon disentuh. Jika Kerang Hijau masih hidup, maka siphonakan bergerak dan cangkangnya terbuka; jika Kerang Hijau mati, maka cangkangnya terbuka dan tubuhnya terdekomposisi atau membusuk. Kerang Hijau yang survive dihitung dan dicek setiap hari selama eksperimen. Hasil dari organisme yang survivetersebut akan dapat menjawab hypothesis atau tidak.

Body condition index (BCI) diukur untuk mengetahui apakah selama eksperimen, Kerang Hijau meningkat atau 
menurun beratnya. Pengukuran diambil 100 individu yang diambil dari Muara Kamal sebelum aklimasi (0 hari), 52 individu setelah pre stress(19 hari), dan 25 individu setelah second stress (55 hari).Selanjutnya bandingkan BCI pada masing-masing periode. Berdasarkan Lucas dan Beninger (1985) untuk menghitung BCI adalah:

$$
\frac{\text { Berat Kering soft tissue }(\mathrm{g})}{\text { Berat kering cangkang }(\mathrm{g})}
$$

\section{HASIL DAN PEMBAHASAN}

\subsection{Hasil survival rate dan Body condition index (BCI)}

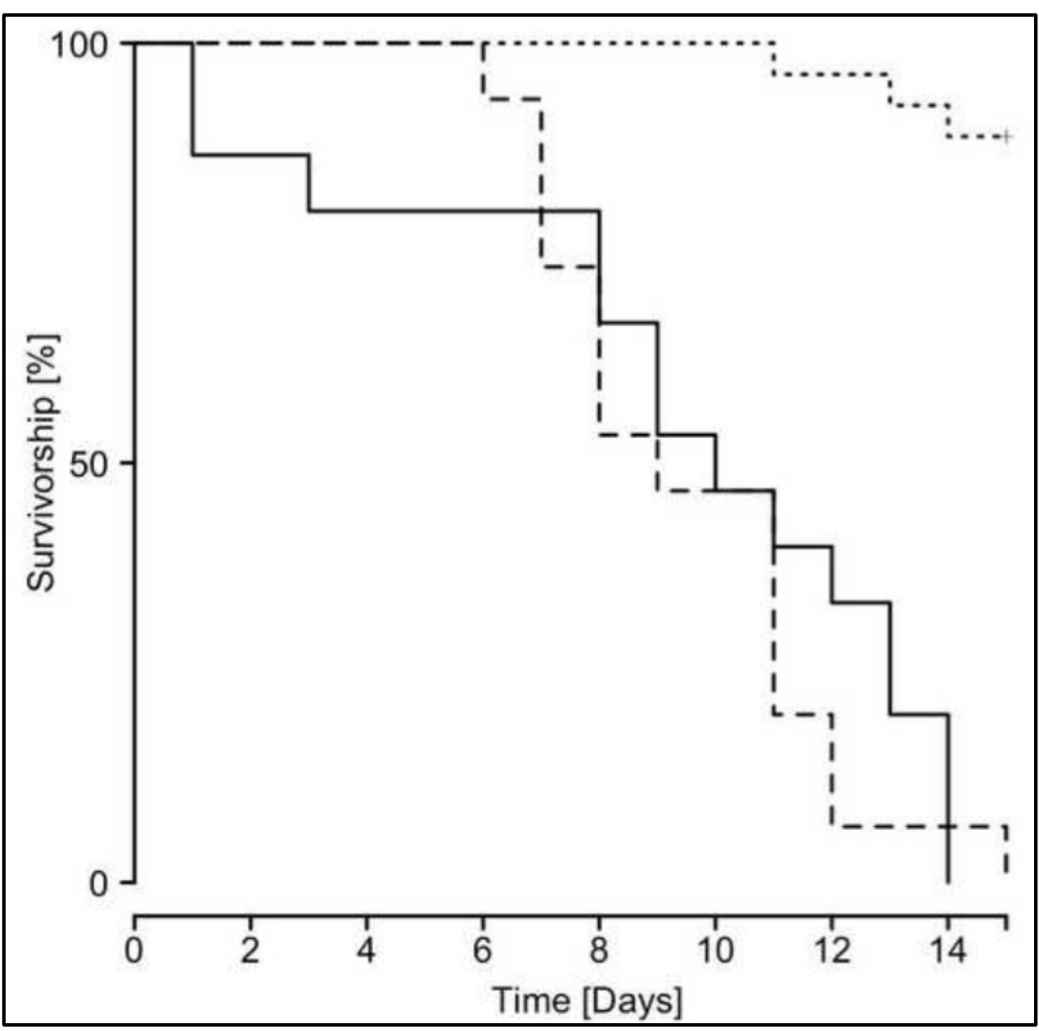

Gambar 2. Survival rate untuk grup pra stresstanpa recovery dibandingkan dengan grup non stress 


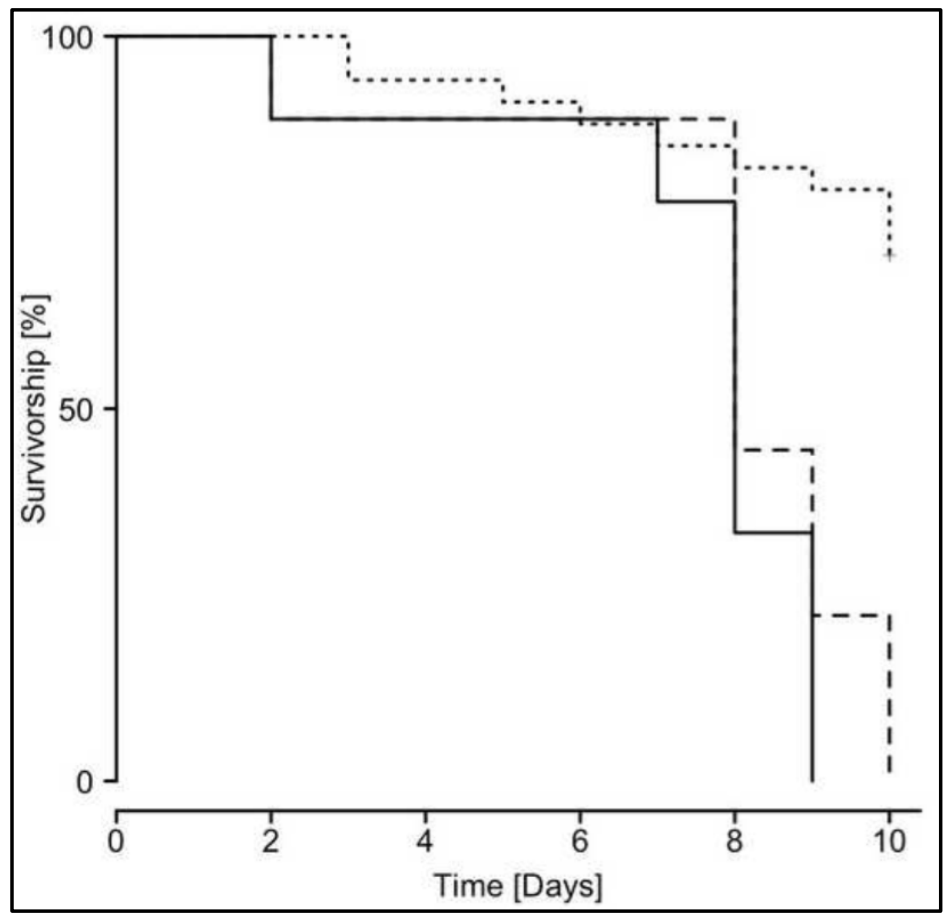

Gambar 3. Survival rate untuk grup pra stress dengan recovery dibandingkan dengan grup non stress

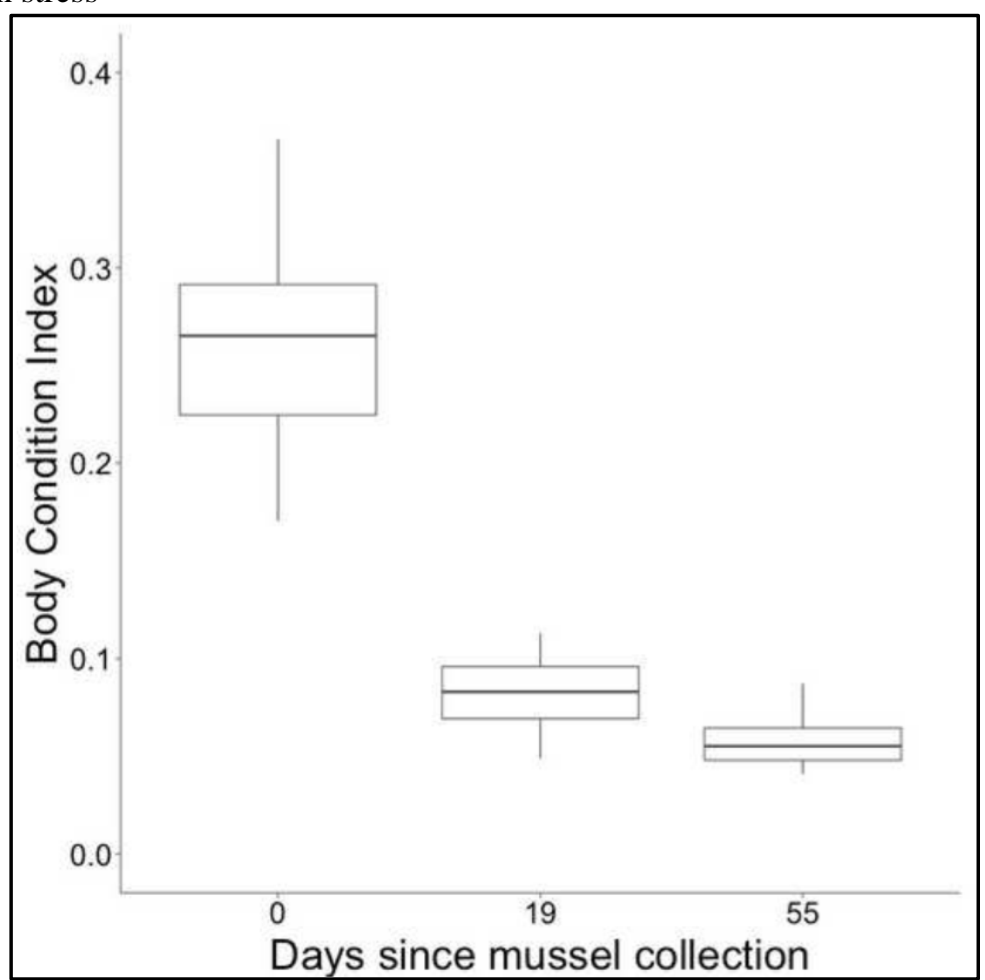

Gambar 4. Body condition index(BCI)

\section{PEMBAHASAN}

Berdasarkan hasil eksperimen menunjukkan bahwa survival rate pada Kerang Hijau memiliki mortalitas yang tidak berbeda jauh atau sama baik grup pra stress dengan dan tanpa recovery. Hal ini menunjukkan bahwa tidak ada perbedaan antara grup pra stress dan grup non stress. Kesimpulan dari eksperimen ini bahwa tidak ada selektivitas atau tidak ada pilihan untuk toleransi terhadap stress karena tidak ada pengaruh pada tingkat genotip dan fenotip.Disisi lainketika terjadi perubahan iklim, Kerang Hijau dapat merespon perubahan suhu maksimum 
hingga $35^{\circ} \mathrm{C}$. Jika melebihi dari suhu tersebut, maka Kerang Hijau akan punah.

Pada tahap pre stress, Kerang Hijau dapat survive selama 16 hari dengan $86 \%$ mortalitas. Setelah itu, Kerang Hijau mulai menurun performanya setelah dilanjutkan langsung ke stress berikutnya dan bertahan hingga 14 hari.Pada saat Kerang Hijau di recovery, maka biota tersebut perlahan menurun daya tahannya.Kerang Hijau menunjukkan memiliki toleransi terhadap suhu berkisar $27^{\circ} \mathrm{C}-35^{\circ} \mathrm{C}$.Namun, organisme tersebut dapat bertahan selama transportasi (Mead et al, 2011).Asumsi ini menunjukkan bahwa biota tersebut meningkat jumlahnya pada saat masuk dalam kapal di pelabuhan (Lewis et al. 2005; Rodriguez, 2006; Briski et al. 2011; Mead et al. 2011) karena temperature di ballast tankmasih dalam kondisi normal atau dibawah $35^{\circ} \mathrm{C}$.Kerang Hijau dapat hidup dengan baik dengan suhu untuk bertahan dan berkembang yaitu $31^{\circ} \mathrm{C}$ dan suhu untuk bermukim yaitu $29^{\circ} \mathrm{C}$ (Nair and Appukuttan, 2003; Rajagopal et al. 2006). Menurut McDonald (2012), Kerang Hijau yang masuk di perairan Australia bagian barat melalui kapal memiliki suhu berkisar $24^{\circ} \mathrm{C}-32^{\circ} \mathrm{C}$ dan biota tersebut dapat memijah dan berkembang. Sedangkan Kerang Hijau yang berada di dalam laboratorium memiliki suhu $2^{\circ} \mathrm{C}\left(27^{0} \mathrm{C}\right)$ lebih dingin dibandingkan dengan suhu yang ada di Muara Kamal.

Muara Kamal merupakan salah satu tempat budidaya kerang hijau yang menggunakan tiang bambu.Lokasi ini juga sangat besar dipengaruhi oleh aktivitas anthropogenic.Mayoritas populasi Indonesia yang di Pulau Jawa berada di Jakarta.Oleh karena itu, sumberdaya pesisir di Jakarta telah banyak dipengaruhi oleh aktivitas manusia seperti budidaya kerang hijau dan setiap tahun menunjukkan peningkatan eutrofikasi dan sedimentasi yang dapat berpengaruh pada komunitas organisme laut (Damar,2003;vanderMeijetal.,2009).

Selama eksperimen,Kerang Hijaumengalami penurunan berat.Sehingga ini membuktikan bahwa meningkatnya temperature berbanding terbalik dengan laju pertumbuhan.Ada beberapa kemungkinan yang terjadi penurunan beratbadan karena pengaruh makanan yang diberikan tidak mencukupi atau Kerang hijau memiliki batas waktu selama di laboratorium. Menurut McDonald (2012), melaporkan bahwa Kerang Hijau yang masuk di Australia bagian Barat melalui kapal dengan temperature $24{ }^{0} \mathrm{C}-32{ }^{\circ} \mathrm{C}$ akan bertumbuh dengan sukses. Menurut Schneider (2008), Mytilus galloprovincialismenunjukkan pertumbuhan maksimal dan survivepada suhu yang dingin $\left(18^{\circ} \mathrm{C}\right)$ dan dapat bertambah jumlahnya pada suhu $25^{\circ} \mathrm{C}$ (Braby and Somero, 2006). Di sisi lain, cahaya pada daerah intertidal memiliki dampak negative terhadap pertumbuhan dan survival organisme (Schneider, 2008).Berdasarkan laporan Lee (1986), pertumbuhan dan temperature memiliki korelasi yang positif dengan batas terendah pada suhu $17{ }^{\circ} \mathrm{C}$.Pemberian makanan dan penyerapannya pada Kerang Hijau menunjukkan korelasi yang signifikan dengan ketersediaan makanan (Wong and Cheung, 2001).Pada eksperimen ini, Kerang Hijau mengalami penurunan berat badan dan berdampak pada survival biota tersebut.

\section{KESIMPULAN DAN SARAN}

\section{Kesimpulan}

Pada eksperimen Kerang Hijau ini menunjukkan bahwa tidak ada selektivitas atau tidak ada pilihan untuk toleransi terhadap stress karena tidak ada pengaruh pada tingkat genotip dan fenotip. Disisi lain ketika terjadi perubahan iklim, Kerang Hijau dapat merespon perubahan suhu maksimum hingga $35^{\circ} \mathrm{C}$. Jika melebihi dari suhu tersebut, maka Kerang Hijau akan mati atau dapat memungkinkan terjadi kepunahan.

Kerang Hijau yang berasal dari pengaruh anthropogenik tidak menunjukkan laju peningkatan survivalrate, sehingga lingkungan yang terkena dampak dari aktifitas anthropogenic, tidak akan berpengaruh pada ketahanannya. 
Hasil dari eksperimen Kerang hijau yang di budidayakan di Muara Karang menunjukkan bahwa terjadi penurunan berat badan selama eksperimen di laboratorium, sehingga berdampak juga pada laju survival rate.Ini membuktikan bahwa meningkatnya temperature berbanding terbalik dengan laju pertumbuhan.Ada beberapa kemungkinan yang terjadi penurunan berat badan karena pengaruh makanan yang diberikan tidak mencukupi atau Kerang hijau memiliki batas waktu selama di laboratorium.

\section{Saran}

Pada eksperimen ini, perlu dibatasi waktu eksperimen Kerang Hijau di laboratorium selama kurang dari sebulan.Selain itu, perlu dipastikan bahwa jumlah pakan yang tersedia cukup untuk memenuhi kerja metabolisme dari Kerang Hijau tersebut.

\section{DAFTAR PUSTAKA}

Baker P, Fajans JS, Arnold WS, Ingrao DA, Marelli DC, Baker SM. 2007.Range and dispersal of a tropical marine invader, the Asian Green Mussel, Perna viridis, in subtropical waters of the southeastern United States.Journal of Shellfish Research, Vol. 26, No. 2, 345-355, 2007.

Bax N, Williamsona A, Aguerob M, Gonzalezb E, Geeves W. 2003. Marine invasive alien species: a threat to global biodiversity. Elsevier science direct Ltd. Marine policy. Doi: 10.1016/S0308-597X(03)00041-1.

Braby C, Somero G. 2006. Following the heart: temperature and salinity effects on heart rate in native and invasive species of blue mussels (Genus Mytilus). J. Exp. Biol. 209, 2554-2556.

ISAC [National Invasive Species Council, Invasive Species Advisory Committee]. 2006. Invasive Species Definition Clarification 6. References State of the Gulf of Maine Report: Marine Invasive Species June 2010 and Guidance Phite 20 Paper.11p. http://www.invasivespecies.gov/global/ISAC/ISAC_index.html.

Kaluza P, Kölzsch A, Gastner MT, Blasius B. 2010. The complex network of global cargo ship movements. Interface journal of the royal society.

Lee JE, Chown SL. 2007. Mytilus on the move: transport of an invasive bivalve to the Antarctic. Marine ecology progress series.Vol. 339: 307-310.

Lenz M, da Gama BAP, Gerner NV, Gobin J, Groener F, Harry A, Jenkins SR, Kraufvelin P, Mummelthei C, Sareyka J, Xavier E, Wahl M. 2011. Non- native marine invertebrates are more tolerant towards environmental stress than taxonomically related native species: Results from globally replicated study. Environmental Research, Elsevier Journal. 943-952 pp.

Lucas, A; Beninger, PG. 1985.The use of physiological condition indices in marine bivalve aquaculture.Elsevier Science Publishers. Amsterdam Netherlands.

Mead A, Carlton JT, Griffiths CL, Rius M. 2011. Revealing the scale of marine bioinvasions in developing regions: a South African re-assessment. Biological invasion. doi:10.1007/s10530-011-0016-9 
Nielsen K. S. 1990. Animal Physiology: Adaptation and Environment, Fourth Edition. Cambridge University Press. 217-236 pp. 